\title{
PENINGKATAN MOTIVASI, BERFIKIR KRITIS MELALUI MODUL PENCEMARAN LINGKUNGAN BERBASIS POE (PREDIKSI, OBSERVASI, EXPLAIN)
}

\author{
Evita Rosilia Dewi \\ STIT Islamiyah Karya Pembangunan Paron Ngawi \\ Email: clintangsalvia@gmail.com
}

Tanggal Submitt:13/01/2022 Tanggal diterima:30/01/2022 Tanggal Terbit:30/01/2022

\begin{abstract}
Biology learning in class X SMA N 1 Kedunggar has not involved students fully because learning is still conventional in nature, thus making students less active in learning. Based on interviews with biology teachers, in the implementation of learning students tend to be less focused and just listen. One of the difficulties in studying biology according to students is because biology material tends to memorize a lot. Improving the quality of learning in schools is done by a variety of strategies, one alternative that can be taken is the development of teaching materials. Learning is needed that applies a factual learning model so that students are able to explore the knowledge gained and be able to think critically like POEbased modules. This module is expected to be able to develop students' motivation and critical thinking in learning, especially in environmental pollution material. This research was designed as a research and development (R\&D). The development of POE-oriented print modules in this study adapted the 4D model (define, design, develop and disseminate) from Thiagarajan, et.al (1974). The results showed that there was an increase in motivation and empowerment of critical thinking through the POE model in learning science on environmental pollution material in SMA Negeri 1 Kedunggalar.

Keywords : Critical Thinking, Module, Motivation, POE
\end{abstract}

\begin{abstract}
Abstrak : Pembelajaran biologi di kelas X SMA N 1 Kedunggar belum melibatkan siswa sepenuhnya karena pembelajaran masih bersifat konvensional, sehingga mengakibatkan siswa kurang aktif dalam pembelajaran. Sesuai wawancara dengan pengajar biologi, dalam pelaksanaan pembelajaran siswa cenderung kurang fokus serta hanya mendengarkan saja. Salah satu kesulitan belajar biologi menurut siswa yaitu karena materi biologi cenderung banyak hafalan. Peningkatan kualitas pembelajaran di sekolah dilakukan menggunakan banyak sekali seni manajemen, salah satu alternatif yang dapat ditempuh adalah pengembangan bahan ajar. Dibutuhkan pembelajaran yang menerapkan model pembelajaran yang bersifat faktual sehingga siswa mampu menggali pengetahuan yang didapat serta mampu berpikir dengan kritis seperti modul berbasis POE. Modul ini diharapkan mampu membuat motivasi serta berfikir kritis peserta didik dalam belajar, khususnya pada materi pencemaran lingkungan. Penelitian ini dibuat menjadi penelitian pengembangan (Research and Development) atau diklaim menggunakan penelitian R\&D. Pengembangan modul cetak berorientasi POE dalam penelitian ini mengadaptasi contoh 4D (define, design, develop and disseminate) dari Thiagarajan, et.al (1974). Hal yang akan terjadi dalam penelitian menunjukkan bahwa adanya peningkatan motivasi serta pemberdayaan berpikir kritis melalui model POE dalam pembelajaran IPA materi pencemaran lingkungan di SMA Negeri 1 Kedunggalar.

Kata Kunci : Berfikir Kritis, Modul, Motivasi, POE
\end{abstract}

\section{Pendahuluan}

Pendidikan pada dasarnya merupakan salah satu upaya buat menyampaikan pengetahuan, wawasan, keterampilan, serta keahlian eksklusif pada individu guna 
menggali serta menyebarkan talenta serta kepribadian. Hal tersebut berkaitan dalam proses pembelajaran yang dilakukan serta kemampuan pendidik dalam membentuk atau menyebarkan kompetensi dasar, kapasitas belajar, serta potensi siswa agar bisa digunakan secara maksimal. Potensi siswa akan dapat dikembangkan jika dalam sebuah proses pembelajaran yang dilakukan merupakan sebuah pembelajaran aktif yang lebih terpusat pada siswa. Pembelajaran yang aktif memberikan kesempatan serta mendorong siswa untuk ikut terlibat selama proses pembelajaran. Selama proses pembelajaran, pengajar dapat mengajarkan peserta didik dalam berbagai bentuk belajar sains seperti belajar penemuan,belajar kelompok, belajar mandiri, serta belajar memecahkan suatu persoalan.

Pembelajaran sains itu sendiri berasal dari proses, produk, serta sikap yang harus dituntut untuk mengajarkan memecahkan suatu problem serta melakukan sebuah inovasi. Biologi merupakan sebuah kajian sains yang mempunyai pengertian relatif luas hal ini dikarenakan biologi itu sendiri memiliki konsep yang luas. Dalam hal ini pengajar harus berupaya serta mengusahakan kepada peserta didik buat mengkaji serta menanamkan konsep yang ada. Pada hal ini konsep biologi meiliki kaitan yang sangat erat dengan kehidupan sehari-hari.dalam mengaitkan sebuah konsep biologi dengan kehidupan seharihari akan sangat menyenangkan. dalam hal ini, kompetensi pengajar akan sangat penting dalam mengembangkan sebuah pembelajaran.

Dengan perkembangan dunia pendidikan saat ini, sekolah adalah lembaga yang harus menyelenggarakan suatu pendidikan yang berguna untuk memberikan bekal pendidikan di masa yang akan datang. Dalam hal ini peserta didik harus dibekali dengan modalitas yang berdasar kepada motivasi belajar serta kemampuan berpikir. Pembelajaran sains dapat menciptakan susasana atau iklim belajar yang menyenangkan serta dapat membangkitkan minat peserta didik untuk mengembankan kreativitas siswa serta menyampaikan ide ataupun gagasan dengan sesuai yang mereka pelajari serta dapat membangkitkan minat siswa untuk mengembankan kreativitas siswa serta menyampaikan ide ataupun gagasan dengan sesuai yang mereka pelajari.

Peningkatan kualitas pembelajaran dapat dilakukan dengan meningkatkan dalam mengembangkan sebuah bahan ajar. Saat ini pengembangan bahan ajar menjadi kebutuhan yang mendesak karena dalam era sekarang ini menuntut pendidik agar mampu mengembangkan metode yang membangkitkan semangat siswa dalam berfikir kritis guna memecahkan persoalan yang selama ini menjadi persoalan dilingkungan sekitar. Modul merupakan salah satu contoh bahan ajar yang berguna untuk meningkatkan minat belajar siswa.dalam hal ini modul dapat membatu sekolah untuk untuk meningkatkan kualitas pembelajaran meningkat lebih baik. penerapan modul mebuat kegiatan pembelajaran menjadi terencana dengan baik, mandiri, tuntas, serta hasil yang jelas.

Modul merupakan salah satu bentuk bahan ajar yang dikemas secara utuh serta sistematis, didalamnya memuat seperangkat pengalaman belajar yang terencana serta didesain untuk membantu peserta didik menguasai tujuan belajar yang spesifik ${ }^{1}$. Saat ini modul pembelajaran sangat banyak serta sangat bervariasi macamnya. Namun, modul yang beredar saat ini kurang menunjang atau mengoptimalkan siswa gar dapat

${ }^{1}$ Presiden Republik Indonesia, "UNDANG-UNDANG REPUBLIK INDONESIA NOMOR 20 TAHUN 2003 TENTANG SISTEM PENDIDIKAN NASIONAL,” Pub. L. No. 20, 26 (n.d.). 
memecahkan suatu persoalan. Salah satu model pembelajaran yang dapat meningkatkan atau mengoptimalkan dalam memecahkan suatu perpersoalanan adalah Predict, Observe, Explain (POE).

Model POE merupakan sebuah rangkaian proses pemecahan persoalan yang dilakukan oleh siswa dengan tahap prediksi atau dugaan awal (predict), pengamatan atau pembuktian dugaan (observe), serta penjelasan terhadap hasil pengamatan (explain). ${ }^{2}$ Pembelajaran POE memerlukan persiapan yang lebih matang terutama berkaitan dengan kegiatan yang akan dilakukan, memerlukan alat, bahan dan tempat yang memadai. Hal ini diharapkan dapat melatih siswa dalam melakukan sebuah prediksi atau sebuah jawaban sementara dari perpersoalanan yang ditentukan oleh pengajar, Sehingga memotivasi siswa agar mampu memecahkan persoalan yang timbul dilingkungan sekitar.

Persoalanan yang dapat diberikan oleh pengajar adalah tentang fenomena atau isu-isu yang ada dilingkungan sekitar mereka. Dalam hal ini menghubungkan sebuah fenomena atau isu yang ada di lingkungan adalah sebuah bentuk pendekatan pembelajaran. Penyajian perpersoalanan dapat diambil berdasarkan fenomena atau isu-isu lingkungan di daerah sekitar. Persoalan diberikan kepada siswa agar kecakapan siswa dapat di terapkan di lingkungan sekitar mereka. Oleh sebab itu, modul perlu dikembangkan agar dapat menunjang belajar siswa serta memecahkan persoalan di kehidupan sehari- hari mereka.

3“'Model pembelajaran POE dapat meningkatkan pehamaman konsep biologi siswa dibandingkan dengan model pembelajaran konvensional". Model pembelajaran POE (predict-observe-explain) adalah salah satu alternatif yang dapat digunakan oleh para guru untuk menciptakan suasana belajar yang menyenangkan dan berkualitas. ${ }^{4}$ Selain itu dalam POE dapat meningkatkan pemahaman konsep sains siswa."

Modul yang berorientasi terhadap POE yang memiliki wawasan terhadap lingkungan akan memiliki kelebihan hal ini dapat mengembangkan minat siswa untuk belajar terhadap lingkungan sekitar mereka. Proses pemecahan persoalan memiliki tiga tahapan yaitu predict, observe, serta expalin. Pertama siswa harus melakukan prediksi atau dugaan awal pada fenomena biologi (predict), melakukan pengamatan atau pembuktian terhadap dugaan (observe), serta yang terakhir adalah menjelaskan hasil pengamatan yang mereka lakukan (explain). Sebelum tahapan predict dilakukan siswa harus menyajikan wacana awal untuk memperkuat konsep serta menggali pengetahuan awal. Setelah siswa mendapatkan konsep awal sebuah materi, kemudian disajikan wacana kedua yang berupa fenomena berupa pencemaran lingkungan yang ada di sekitar, setelah itu siswa harus melakukan sebuah prediksi terhadap fenomena tersebut. Pada tahap ini juga harus

\footnotetext{
${ }^{2}$ Cipta Suhud Wiguna, "Pengaruh Model Pembelajaran Poe Terhadap Pemahaman Konsep Dan Kemampuan Berpikir Kreatif Peserta Didik.," Jurnal Geografi Gea 13, no. 1 (August 19, 2016), https://doi.org/10.17509/gea.v13i1.3306.

3 "PENGARUH MODEL PEMBELAJARAN POE (PREDICT-OBSERVEEXPLAINT)TERHADAP PEMAHAMAN KONSEP FISIKA DAN SIKAP ILMIAH DITINJAU DARI GAYA BELAJAR SISWA | RESTAMI | Jurnal Pendidikan Dan Pembelajaran IPA Indonesia," accessed January 29, 2022, https://ejournal-pasca.undiksha.ac.id/index.php/jurnal_ipa/article/view/716.

4 "PENGEMBANGAN MODUL BERORIENTASI POE (PREDICT, OBSERVE, EXPLAIN) BERWAWASAN LINGKUNGAN PADAMATERI PENCEMARAN UNTUK MENINGKATKAN HASIL BELAJAR SISWA | Widyaningrum | Bioedukasi: Jurnal Pendidikan Biologi," accessed January 29, 2022, https://jurnal.uns.ac.id/bioedukasi/article/view/3920.
} 
dilengkapi dengan gambar atau ilustrasi agar siswa dapat tertarik. Tahap observe berupa laboratorium mini yang merupakan Lembar Kerja Siswa (LKS). Sedangkan pada tahap explain siswa diminta menjelaskan hasil dari observasi atau eksperimen. Modul ini juga dilengkapi dengan fitur berita.

Pembelajaran sains dengan menggunakan modul akan sangat bermanfaat bagi pengajar dikarenakan dalam menyampaikan materi akan sangat mudah dijelaskan kepada siswa sehingga hal itu dapat mudah dimengerti oleh siswa itu sendiri. Modul selain untuk siswa belajar mandiri, modul juga dapat digunakan untuk diskusi atau berkelompok karena siswa akan berfikir untuk memecahkan suatu persoalan di dalam sebuah kelompok.

Dalam mewawancarai salah satu pengajar, pengajar tersebut menyebutkan dalam pelaksanaan pembelajaran materi tentang pencemaran lingkunganditemukan kendala materi yang belum optimal dikaji berbagai persoalan ataupun kasus yang berkaitan dengan persoalan yang ada dilingkungan sekitar. Salah satu kesulitan dalam belajar biologi adalah banyaknya hafalan yang harus dihafal oleh siswa tersebut.pada hal ini siswa akan cenderung pasif,kurang bergairah, serta kurang bersemangat dalam mendengarkan materi tentang biologi. sehingga dalam pembelajaran suasana akan sangat membosankan serta pasif. Dalam hal ini, belum tersedia juga modul yang spesifik yang mengulas tentang berbagai macam perpersoalanan yang ada di daerah, khususnya di daerah Ngawi. Dalam hal ini siswa akan banyak mengandalkan sumber belajar dari buku paket serta catatan siswa yang akan berdampak kurang optimalnya hasil belajar siswa.

\section{Metode Penelitian}

Penelitia ini menggunaka sisten penelitian pengembangan (Research and Developmet) atau biasa disebut dengan penelitian R\&D. Research and Development adalah sebuah proses yang dapat mengembangkan sebuah produk baru ataupun menyempurnakan sebuah produk yang bertujuan untuk mengembangkan modul.dalam hal ini produk yang dumaksud adalah modul cetak. Dalam hal bentuk penelitian pengembangan ini merupakan pengembangan modul cetak yang akan berisi tentang materi pencemaran lingkungan yang akan berorientasi pada POE.

Pada metode penelitian dan pengembangan terdapat beberapa jenis model. Model yang digunakan adalah pengembangan model 4D. Model pengembangan 4D merupakan model pengembangan berbagai macam jenis media pembelajaran yang bersifat umum, dimana bisa digunakan untuk mengembangkan berbagai macam jenis media pembelajaran. Model ini dikembangkan oleh Sivasailam Thiagarajan, Dorothy S. Semmel, dan Melvyn I. Semmel. Model pengembangan 4D terdiri dari 4 tahap utama, yaitu Define atau Pendefinisian, Design atau tahap Perancangan, Develop atau merupakan tahap Pengembangan, serta Disseminate atau tahapan untuk Penyebaran. Lembar validasi modul biologi, merupakan instrumen yang digunakan pada tahap pengujian produk oleh beberapa ahli. Sedangkan lembar observasi adalah instrumen untuk meninjau keefektivitasan penggunaan modul biologi berbasis POE pada materi usaha dan energi yang ditinjau dari kemampuan kognitif siswa. Analisis yang dilakukan pada penelitian ini yaitu dengan cara mengelompokan jenis-jenis data yang diperoleh sehingga peneliti mudah memahami data dan menarik kesimpulan. 


\section{Pembahasan}

\section{Hasil Belajar}

Berdasarkan hasil dari analisis, nilai kognitif dalam sebuah kelas mengalami peningkatan. Hal ini mampu terjadi sebab peserta didik mulai terbiasa menggunakan modul yang mempunyai basis $P O E$ yang dikembangkan. Siswa juga akan lebih aktif pada bekerja sama dengan teman ketika melakukan pengamatan serta diskusi dalam kelas .

Tabel 1

Nilai Pre-Post Test hasil Belajar Kognitif

\begin{tabular}{|c|c|c|}
\hline \multirow{2}{*}{ Perbandingan } & \multicolumn{2}{|c|}{ Kelas XA 1} \\
\hline & Pretes & Postes \\
\hline Maksimum & 80 & 95 \\
\hline Minimum & 55 & 70 \\
\hline Rata-rata & 60.58 & 79.52 \\
\hline Deviasi & 8.280 & 5.328 \\
\hline
\end{tabular}

Data hasil penilaian yang disajikan merupakan hasil penilaian lembar observasi dapat dilihat pada

Tabel .2.

Hasil Belajar Psikomotorik

\begin{tabular}{|c|c|c|c|}
\hline \multirow{2}{*}{ Kelas } & \multicolumn{3}{|c|}{ Pertemuan (\%) } \\
\cline { 2 - 4 } & I & II & III \\
\hline XA-1 & 93.59 & 96.09 & 98.05 \\
\hline
\end{tabular}

Dalam hal ini Pembelajaran biologi,menekankan interaksi siswa dengan objek yang mereka pelajari. Hal ini akan membuat siswa melakukan interaksi agar siswa belajar untuk mengembangkan kepribadian, keterampilan serta mengenal perpersoalanan biologis beserta dengan pengkajiannya. Dalam hal proses belajar biologi harus mengembangkan tiga ranah yaitu afektif, psikomotorik, serta kognitif.

Berdasarkan skor observasi dari kemampuan kognitif dapat dinyatakan bahwa modul biologi berbasis POE yang dikembangkan berada pada kriteria "tinggi" ${ }^{5}$ Model POE adalah teknik pembelajaran yang banyak dikembangkan dalam pendidikan sains. Teknik ini dilandasi oleh teori pembelajaran konstruktivisme yang beranggapan bahwa melalui kegiatan melakukan prediksi, observasi dan menerangkan sesuatu hasil pengamatan, maka struktur kognitifnya akan terbentuk dengan baik. Anggapan yang lain adalah bahwa pemahaman siswa saat ini dapat ditingkatkan melalui interaksinya dengan rekan sebayanya dalam kelas. Hal ini menunjukan bahwa modul biologi berbasis POE dapat digunakan dalam pelajaran di kelas maupun digunkan belajar secara mandiri oleh siswa.

5 Warsono, Pembelajaran aktif: teori dan asesme (Bandung: Remaja Rosdakarya, 2013), http:// kin.perpusnas.go.id/DisplayData.aspx?pId=51237\&pRegionCode=JIUNMAL\&pClientId=111. 
Hasil dari belajar afektif dapat diketahui dari setiap pelaksanaan pembelajaran. Evaluasi afektif siswa dilakukan oleh tiga orang pengamat serta lembar observasi. Data dari hasil penilaian yang dapat disajikan merupakan hasil dari penilaian lembar observasi afektif hal ini dapat dilihat pada Tabel 3.

Tabel 3.

Hasil Belajar Afektif

\begin{tabular}{|c|c|c|c|}
\hline \multirow{2}{*}{ Kelas } & \multicolumn{3}{|c|}{ Pertemuan (\%) } \\
\cline { 2 - 4 } & I & II & III \\
\hline XA-1 & 88.28 & 92.45 & 94.79 \\
\hline
\end{tabular}

Berdasarkan Tabel 3 dapat diketahui bahwa hasil belajar afektif pada pertemuan pertama adalah $88.28 \%$. Pertemuan kedua sebesar $92.45 \%$ serta pertemuan ketiga adalah $94.79 \%$.

\section{Motivasi belajar siswa}

Motivasi berasal dari kata motif yang dapat diartikan sebagai kekuatan yang terdapat dari individu yang menyebabkan individu tersebut bertindak dan berbuat. Motivasi juga dapat dikatakan sebagai daya penggerak dari dalam dan didalam subjek untuk melakukan aktivitasaktivitas tertentu demi mencapai suatu tujuan ${ }^{6}$. Motivasi itu dapat dirangsang oleh faktor dari luar tetapi motivasi itu adalah tumbuh didalam diri seseorang. Dalam kegiatan belajar mengajar,motivasi dapat dikatakan sebagai keseluruhan daya penggerak didalam diri peserta didik yang menimbulkan kegiatan belajar, yang menjamin kelangsungan dari kegiatan belajar sehingga tujuan yang dikehendaki oleh subjek belajar itu dapat tercapai dan merupakan faktor psikis yang bersifat non-intelektual denga perananya yang khas dalam penumbuhan gairah, merasa senang dan semangat untuk belajar. Peserta didik yang memiliki motivasi yang kuat ${ }^{7}$. Tabel 4.

Dari data hasil motivasi belajar siswa yang diperoleh dari angket, disajikan pada

Tabel 4

Data Motivasi Siswa

\begin{tabular}{|c|c|c|}
\hline \multirow{2}{*}{ Perbandingan } & \multicolumn{2}{|c|}{ Kelas XA 1 } \\
\cline { 2 - 3 } & Pretes & Postes \\
\hline Maksimum & 80 & 90 \\
\hline Minimum & 52.5 & 62.5 \\
\hline Rata-rata & 61.94 & 84.86 \\
\hline Deviasi & 9.460 & 6.758 \\
\hline
\end{tabular}

Dari hasil analisis data yang ada, nilai motivasi mengalami peningkatan. Hal ini bisa terjadi dikarenakan siswa mulai tertarik menggunakan modul yang berbasis POE yang

${ }^{6}$ Hamzah B Uno, Teori Motivasi \& Pengukurannya (Bumi Aksara, 2007).

7 Ghullam Hamdu and Lisa Agustina, "PENGARUH MOTIVASI BELAJAR SISWA TERHADAP PRESTASI BELAJAR IPA DI SEKOLAH DASAR” 12 (2011): 82-90. 
dikembangkan. Serta peserta didik mulai aktif buat bekerja sama dengan teman sekelas waktu melakukan pratikum serta diskusi kelas.

Dari hasil analisis tersebut, afektif peserta didik mengalami peningkatan. Hal ini bisa terjadi dikarenakan siswa sudah mulai terbiasa dengan modul yang dikembangkan. Siswa juga lebih aktif dalam berdiskusi didalam kelas serta termotivasi untuk melakukan kolaborasi dengan teman saat melakukan pratikum. Hasil belajar psikomotor mengalami kenaikan juga karena pada setiap pertemuan peserta didik sudah terbiasa dengan metode pratikum, maka dengan itu keterampilan siswa memakai alat juga semakin baik. Hal ini dilakukan oleh guru supaya siswa berpikir secara matang. Sesuatu yang menarik minat peserta didik pasti mereka akan melakukannya. Usaha menumbuhkan keingintahuan peserta didik yang diharapkan pada kegitan pembelajaran dengan memelihara serta membangkitkannya. Dengan adanya kedua tahapan tersebut akan menyebabkan motivasi belajar siswa meningkat.

\section{Kemampuan Berpikir Kritis Siswa}

Kemapuan berpikir kritis siswa dapat kita nilai dari awal pelaksanaan pembelajaran serta akhir pelaksanaan pembelajaran . kita dapat menilai kemampuan berpikir kritis siswa dengan menggunakan aspek yang merujuk pada facione. Dari data hasil penilaian yang dapat disajikan adalah hasil penilaian lembar observasi afektif yang dapat dilihat pada Tabel 5.

Tabel 5

Tabel kemampuan berpikir kritis siswa

\begin{tabular}{|c|c|c|}
\hline \multirow{2}{*}{ Kelas } & \multicolumn{2}{|c|}{ Pertemuan (\%) } \\
\cline { 2 - 3 } & Awal & Akhir \\
\hline XA-1 & 69.35 & 76.94 \\
\hline
\end{tabular}

Dari hasil uji kemampuan berpikir kritis siswa didapatkan data yang diperoleh dari tes kemampuan berpikir kritis siswa. Dari kenaikan hasil kemampuan berpikir kritis siswa diperoleh hasil yaitu kenaikkanya tergolomg rendah. Dari aanalisis uji prasayarat didapatkan bahwa kelas memiliki data yang terdistribusi normal serta homogen, serta dengan diuji dengan paired sample t-test didapatkan bahwa setiap pembelajaran mengalami perbedaan. Dari analisis tersebut di buktikan bahwa setiap pembelajaran mengalami perbedaan. Dilihat dari pertemuan pertama hingga pertemuan terakhir, terdapat kenaikan kemampuan berpikir kritis siswa.

Kemampuan berpikir kritis menurut Facione (2010: 2-5) diartikan sebagai kemampuan berpikir seseorang secara baik tentang suatu objek perpersoalanan ${ }^{8}$. Kemampuan berpikir kritis mencakup kemampuan dalam mengklarifikasi makna dari suatu materi pembelajaran (interpretation), kemampuan dalam memeriksa gagasan, mengidentifikasi argumen, serta menganalisis argumen (analysis), kemampuan dalam menilai suatu pernyataan atau argumen (evaluation), kemampuan dalam menyatakan

8 N. C. Facione and P. A. Facione, "Externalizing the Critical Thinking in Knowledge Development and Clinical Judgment," Nursing Outlook 44, no. 3 (June 1996): 129-36, https://doi.org/10.1016/s0029-6554(06)80005-9. 
persoalan, mengemukakan kebenaran prosedur serta argument (explanation), kemampuan dalam mempertanyakan pernyataan, memikirkan suatu solusi atau jawaban dari perpersoalanan yang muncul, memecahkan persoalan, mengambil suatu keputusan, serta menarik kesimpulan (inference), serta kemampuan dalam meneliti diri serta mengoreksi diri (self-regulation). Keenam kemampuan tersebut merupakan aspek-aspek kemampuan berpikir kritis.

Dengan kemampuan modul dalam memberdayakan kemampuan berpikir kritis, motivasi, serta hasil belajar kognitif dapat menunjukkan efektivitas modul tersebut. Dalam memberdayakan kemampuan modul perlu untuk membandingkan hasil pretes serta postes serta motivasi siswa dengan menggunakan uji t berpasangan. Dengan hasil uji t berpasangan diperoleh modul yang sesertag dikembangkan mempunyai kemampuan yang baik dalam memberdayakan kemampuan berpikir kritis siswa, serta hasil belajar kognitif serta motivasi siswa . dari hasil uji t berpasangan bahwa taraf signifikasi sebesar $0,000<0,05$, yang artiya terdapat nilai perbedaan pada pretes serta postes kemampuan berpikir kritis. Dari hasil uji t berpasangan pretes serta postes motivasi diperoleh hasil taraf signifikasi $0,000<0.05$, dengan hal ini ada perbedaan dalam nilai pretes serta postes motivasi. Dari hasil uji t berpasangan postes serta pretes belajar kognitif diperoleh $0,000<0,05$, hal tersebut ada perbedaan nilai postes serta pretes hasil belajar kognitif.

Dalam hal ini pembelajaran dengan menggunakan modul berbasis pembelajaran POE memiliki akibat kenaikan hasil belajar walaupun kenaikan itu tidak terlalu tinggi. Modul akan menghasilkan pembelajaran yang lebih menarik. Tentunya dengan hal ini akan menarik minat siswa terhadap belajar akan semakin tinggi walaupun tidak terlalu tinggi.

Dengan belajar memakai modul yang berbasis POE siswa secara mandiri mampu belajar dimanapun serta kapanpun. Dengan tindakan mandiri siswa bisa menghubungkan pengetahuan akademik mereka dengan kehidupan sehari-hari yang mereka lakukan sehingga tujuan yang memiliki makna akan segera tercapai. Dengan siswa melakukan pembelajaran mandiri bisa mendapatkan informasi dengan cara mengamati, mendengarkan, membaca, atau dengan cara berdiskusi. Setelah melakukan perhitungan dengan cara perhitungan $\mathrm{N}$-gain ternomalisasi, maka hasil belajar yang selanjutnya dilakukanlah uji prasyarat sebelum dilakukannya uji lanjut. Dari hasil analisi yang dilakukan dengan analisis pretes serta postes diketahui bahwa distribusinya normal serta homohen berikutnya yang dianalisis dengan uji paired t-test (uji t dua sampel berpasangan). Hal ini diketahui bahwa $\mathrm{H}_{\mathrm{o}}$ ditolak. Hal ini menujukkan perbedaan nilai hasil belajar siswa sebelum serta setelah dibeikannya modul yang berorientasi pada POE. Modul berorientasi POE hal ini dikembangkan untuk salah satu alternatif oleh pengajar yang digunakan sebagai dasar untuk melakukan kegiatan pembelajaran yang baik serta bermutu.

Model POE adalah teknik pembelajaran yang banyak dikembangkan dalam pendidikan sains?. Teknik ini dilandasi oleh teori pembelajaran konstruktivisme yang beranggapan bahwa melalui kegiatan melakukan prediksi, observasi dan menerangkan sesuatu hasil pengamatan, maka struktur kognitifnya akan terbentuk dengan baik.

${ }_{9}$ Pembelajaran aktif: teori dan asesme. 
Penerapan model pembelajaran POE dapat meningkatkan pembelajaran IPA, dan efektif dalam meningkatkan pemahaman konsep serta meningkatkan aktivitas dan hasil belajar siswa ${ }^{10}$. Menurut teori konstruktivisme, satu prinsip yang paling penting dalam psikologi pendidikan adalah bahwa guru tidak hanya sekedar memberikan pengetahuan kepada siswa. Namun mereka harus membangun sendiri pengetahuan didalam benak mereka. Guru hanya sebagai fasilitator misalnya memberikan kesempatan untuk siswa menemukan ide-ide mereka sendiri. Model pembelajaran POE berhubungan dengan konstruktivisme, karena dalam sintak model POE yaitu pada tahap predict, menuntut siswa untuk aktif misalnya dalam membuat prediksi dan aktif untuk mengemukakan pendapatnya. Bukan hanya proses transfer pengetahuan secara langsung dari guru ke siswa. ${ }^{11}$

Dalam penelitian ini digunakan beberapa analisis untuk menguatkan hasil temuan yang nantinya menjadi hasil akhir penelitian.

a. Analisis Data Hasil Ujian Nasional

Siswa SMA itu sendiri harus dituntut untuk berpikir kritis serta memiliki hasil belajar yang memuaskan. Kenyataan menunjukkan sebagian besar kemampuan berpikir kritis serta hasil belajar siswa SMA tergolong rendah. Kemampuan siswa untuk berpikir kritis rendah dilihat dari hasil UN SMA pada tahun 2012 menunjukkan bahwa sebagian besar siswa SMAN 1 Kedunggalar kurang menguasai materi pencemaran lingkungan. Persentase ketuntasan KD UN SMA/MA pada tahun 2012 SMAN 1 Kedunggalar pada materi pencemaran lingkungan hanya sebesar 59,46.

b. Analisis Peserta Didik

Kemampuan berpikir kritis diperoleh kemampuan awal rata-rata dari 29 siswa kelas X SMAN 1 Kedunggalar sebesar 53,10 tergolong rendah. Motivasi awal rata-rata dari 29 siswa kelas X SMAN 1 Kedunggalar sebesar 57,75 tergolong rendah. Hasil belajar kognitif diperoleh kemampuan awal rata-rata dari 29 siswa kelas X SMAN 1 Kedunggalar sebesar 56,48 tergolong rendah.

c. Tahap Uji Lapangan Operasional (Uji Efektivitas)

tahap uji efektivitas guna dilakukannya untuk mengetahui sejauh mana modul itu mampu memberdayakan kemampuan siswa untuk berpikir kritis,serta mengetahui hasil belajar kognitif, serta memotivasi siswa. Hasil uji t berpasangan menunjukkan bahwa modul yamg dikembangkan memiliki kemampuam yang sangat baik dalam memberdayakan kemampuan siswa agar berpikir kritis, memiliki hasil belajar kognitif,serta memotivasi siswa. Oleh sebab tidak ada revisi dalam hal yahap uji lapangan operasional.

10 Fanny Sumirat, "Efektivitas Model Pembelajaran Predict-Observe-Explain Untuk Meningkatkan Keterampilan Berpikir Kritis Dan Memfasilitasi Perubahan Konseptual Siswa Sekolah Dasar" (masters, Universitas Pendidikan Indonesia, 2012), http://repository.upi.edu.

11 Trianto Ibnu Badar Al-Tabany, Mendesain Model Pembelajaran Inovatif, Progresif, Dan Konteksual (Prenada Media, 2017). 


\section{Catatan Akhir}

Modul berorientasi POE bisa memberdayakan motivasi serta berpikir kritis peserta didik pada materi pencemaran lingkungan memiliki karakteristik yang singkron menggunakan tahapan dalam POE yaitu 1) para peserta didik diperkenalkan pada suatu situasi sehingga peserta didik akan mampu membuat ramalan didasarkan pada pengalaman; 2) siswa diminta untuk membuat suatu ramalan serta memberi alasan; 3) dilakukan suatu kegiatan pengamatan; 4) para siswa akan dapat menjelaskan akan besertaya antara apa yang mereka ramalkan dengan hasil yang mereka amati; 5) para peserta didik diminta mengusulkan gagasan baru buat menyebutkan pemahaman mereka.

\section{Daftar Rujukan.}

Al-Tabany, Trianto Ibnu Badar. Mendesain Model Pembelajaran Inovatif, Progresif, Dan Konteksual. Prenada Media, 2017.

B Uno, Hamzah. Teori Motivasi \& Pengukurannya. Bumi Aksara, 2007.

Facione, N. C., and P. A. Facione. "Externalizing the Critical Thinking in Knowledge Development and Clinical Judgment." Nursing Outlook 44, no. 3 (June 1996): 129_ 36. https://doi.org/10.1016/s0029-6554(06)80005-9.

Hamdu, Ghullam, and Lisa Agustina. "Pengarub Motivasi Belajar Siswa Terhadap Prestasi Belajar Ipa Di Sekolah Dasar" 12 (2011): 82-90.

"Pengaruh Model Pembelajaran POR (Predict-Observe-Explaint) Terhadap Pemahaman Konsep Fisika dan Sikap Ilmiah Ditinjan Dari Gaya Belajar Siswa | RESTAMI | Jurnal Pendidikan Dan Pembelajaran IPA Indonesia." Accessed January 29, 2022. https://ejournal-pasca.undiksha.ac.id/index.php/jurnal_ipa/article/view/716.

"Pengembangan Modul Berorientasi Poe (Predict, Observe, Explain) Berwawasan Lingkungan Padamateri Pencemaran Untuk. Meningkatkan Hasil Belajar Siswa | Widyaningrum | Bioedukasi: Jurnal Pendidikan Biologi." Accessed January 29, 2022. https://jurnal.uns.ac.id/bioedukasi/article/view/3920.

Presiden Republik Indonesia.Undang-Undang Republik Indonesia Nomor 20 Tahun 2003 Tentang Sistem Pendidikan Nasional, Pub. L. No. 20, 26 (n.d.).

Sumirat, Fanny. "Efektivitas Model Pembelajaran Predict-Observe-Explain Untuk Meningkatkan Keterampilan Berpikir Kritis Dan Memfasilitasi Perubahan Konseptual Siswa Sekolah Dasar." Masters, Universitas Pendidikan Indonesia, 2012. http:// repository.upi.edu.

Warsono. Pembelajaran aktif: teori dan asesme. Bandung: Remaja Rosdakarya, 2013. http:/ / kin.perpusnas.go.id/DisplayData.aspx?pId=51237\&pRegionCode=JIUN MAL\&pClientId=111.

Wiguna, Cipta Suhud. "Pengaruh Model Pembelajaran Poe Terhadap Pemahaman Konsep Dan Kemampuan Berpikir Kreatif Peserta Didik." Jurnal Geografi Gea 13, no. 1 (August 19, 2016). https://doi.org/10.17509/gea.v13i1.3306. 